\title{
Uptake of soil P, Al, Fe, Mn, Mg and Ca by Italian rye grass (Lolium multiflorum Lam.) induced by synthetic chelating agent
}

\author{
HELINÄ HARTIKAINEN
}

Department of Agricultural Cbemistry, University of Helsinki, 00710 Helsinki 71

\begin{abstract}
The effect of a synthetic chelating compound on the dry matter yield and the uptake of soil P, Al, $\mathrm{Fe}, \mathrm{Mn}, \mathrm{Mg}$ and $\mathrm{Ca}$ by Italian rye grass was studied in a pot experiment with three mineral soil samples irrigated with water or $0.001 \mathrm{M} \mathrm{Na}_{2}$-EDTA (dinatrium salt of ethylenediaminetetraacetic acid) solution. The $\mathrm{Na}_{2}$-EDTA treatment seemed not to affect the quantity of the dry matter yields, but it affected markedly their chemical composition. Increased contents of P, Al and Fe were found in all the harvests. In two soil samples the $\mathrm{P}$ supply was improved by $35-45 \%$. The accumulation of $\mathrm{Al}, \mathrm{Fe}$ and $\mathrm{Mn}$ induced by $\mathrm{Na}_{2}$-EDTA tended to be the more effective the greater the stability constant for the corresponding metal-EDTA chelate was. Thus, the iron uptake increased most intensively, i.e. by $217-458 \%$, and that of aluminium by $33-120 \%$. On the basis of the first two harvests the manganese absorption by the rye grass seemed to decrease probably due to the enormous accumulation of iron. The results also suggested that the addition of $\mathrm{Na}_{2}$-EDTA to the soil was not able essentially to affect the magnesium and calcium supply to the plants.
\end{abstract}

\section{Introduction}

Metal chelation reactions affect the mobility and availability of many soil elements and plant nutrients. They are of importance in numerous chemical, physical and biological processes in nature. In podsolization, for example, chelation plays an essential role in the development of the soil profile.

Synthetic chelates (e.g. salts of EDTA, EDDTA, DTPA) are used as micronutrient fertilizers to supply plants with iron, copper, zinc and manganese. In Finland EDTA (ethylenediaminetetraacetic acid) chelates are mainly used for this purpose. EDTA may find its way into the soil and surface waters also with industrial wastes, as it is quite commonly used for example as a stabilizer in manufactured products and as a component in various reaction mixtures.

Organic complexing agents are capable of improving the availability of phosphorus in soils by preventing sorption or by mobilizing sorbed reserves. The aim of this study was to demonstrate the role of a synthetic chelating compound, $\mathrm{Na}_{2}$ EDTA, in the uptake of phosphorus by the shoots of rye grass. Furthermore, because chelation increases the mobility of many other plant nutrients as well as elements non essential or toxic to plants, the simultaneous accumulation of some metals and earth alkali metals in rye grass and their possible influence on yields were also studied. 
Materials and methods

a. Experimental soils

The test was carried out with three surface soil samples the characteristics of which are given in Table 1. The particle size composition of the mineral material in the soils was determined by the method of ELONEN (1971). Soil pH was measured in $0.01 \mathrm{M} \mathrm{CaCl}_{2}$ solution in the ratio of soil to solution of 1 to 2.5 . The content of organic carbon was determined by a modified WALKLEY and BLACK wet combustion method (GRAHAM 1948). Exchangeable $\mathrm{Na}, \mathrm{K}, \mathrm{Ca}$ and $\mathrm{Mg}$ were extracted by four successive treatments with $1 \mathrm{M} \mathrm{NH}{ }_{4} \mathrm{OAc}(\mathrm{pH} 7.0)$ and exchangeable $\mathrm{Al}$ by four successive treatments with $1 \mathrm{M} \mathrm{KCl}$ in the ratio of soil to solution of 1 to $S(\mathrm{w} / \mathrm{v})$. The contents of $\mathrm{Al}, \mathrm{Fe}$ and $\mathrm{Mn}$ were studied by extracting the soil for two hours in $0.05 \mathrm{M} \mathrm{NH}_{4}$-oxalate solution ( $\mathrm{pH} \mathrm{3.3),} \mathrm{the} \mathrm{ratio} \mathrm{of} \mathrm{soil} \mathrm{to}$ solution being $1: 20(\mathrm{w} / \mathrm{v})$. The soil inorganic $\mathrm{P}$ reserves were determined by a modified CHANG and JACKSON (1957) fractionation method.

\section{b. Pot experiment}

The pot experiment was performed in a greenhouse with four replicates. The soils weighed into plastic test pots (1.2 kg of sandy clay (1), $1.2 \mathrm{~kg}$ of silt soil (2) and $0.9 \mathrm{~kg}$ of silty clay (3)) were incubated at field capacity for three days. When 50 seeds of Italian rye grass (Lolium multiflorum Lam.) had been sown, the pots were covered with $200 \mathrm{~g}$ of washed quartz sand.

During the test the soils were irrigated, when necessary, with either distilled water or $0.001 \mathrm{M} \mathrm{Na}_{2}$-EDTA solution. No leaching from the pots took place. All the treatments of the silt and silty clay soils (2 and 3) received equal amounts of either one of the liquids, $10200 \mathrm{ml}$ in all. But the sandy clay soil sample (1) was irrigated with $8250 \mathrm{ml}$ of water and with only $6450 \mathrm{ml}$ of $\mathrm{Na}_{2}$-EDTA solution owing to the declined growth after the second harvesting. Before the emergency of the rye grass the $\mathrm{pH}$ of the $\mathrm{Na}_{2}$-EDTA solution (5.3) was raised to 7.0 by $\mathrm{NaOH}$.

Five weeks after the sowing all the pots were fertilized twice with $50 \mathrm{ml}$ of $\mathrm{KNO}_{3}$ solution containing $1000 \mathrm{mg} \mathrm{N}$ per liter. This was repeated two weeks after the first harvesting. Three weeks after the second harvesting $50 \mathrm{ml}$ of $\mathrm{KNO}_{3}$

Table 1. Characteristics of experimental soil samples.

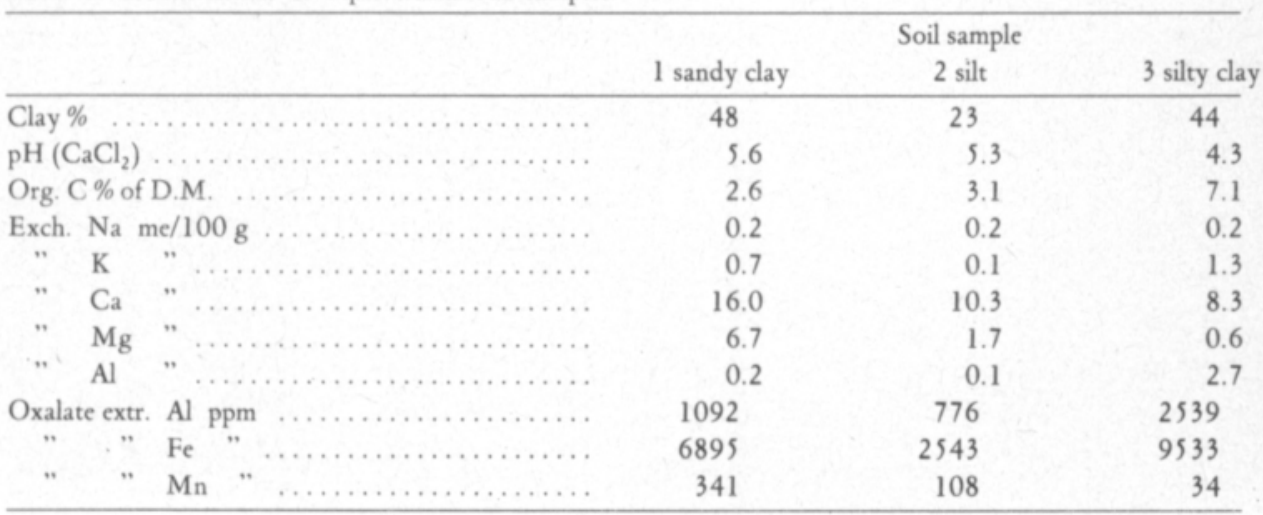


solution was added and another three weeks later the soil samples 2 and 3 received an extra $25 \mathrm{ml}$ of $\mathrm{KNO}_{3}$.

The harvested shoots were air-dried and weighed, and the total contents of various elements in the plant material were determined by dry ashing. All the yields were analysed for phosphorus (by an ammoniumvanadate method), aluminium (by a modified Aluminon method according to YUAN and FISKELL 1959) and iron (by the sulphosalisylic acid procedure of KOUTLER-ANDERSSON 1953). In addition, the contents of manganese, magnesium and calcium in the first two yields were determined by an atomic absorption spectrofotometer.

\section{Results}

The dry matter yields are presented in Table 2 with 95 per cent confidence limits. The sandy clay soil pots being harvested only three times owing to poor growth, the total dry matter yields of this soil remained lower than those of the other experimental soils. The highest dry matter yields were produced by the silt soil (2). In all the soil samples the differences between the treatments were not statistically significant, but it was observed that the plant growth tended to be somewhat reduced in the pots irrigated with $\mathrm{Na}_{2}$-EDTA solution as compared to that in the pots irrigated with water.

In all the soil samples the treatments differed in the contents of various elements in the shoots. Because of this the amounts of elements taken up by the yields could vary markedly even though the dry matter yields were of the same magnitude. The $\mathrm{Na}_{2}$-EDTA treatment regularly tended to increase the content of phosphorus, aluminium and iron in the plants. It seemed to become more effective towards the end of the experiment: the contents in the fourth harvest were higher than those in the earlier ones.

The quantities of various elements taken up by the yields are shown in Table 3 with 95 per cent confidence limits. The addition of the chelating agent did not affect the phosphorus supply to plants in the soil sample 1. On the contrary, it intensified the phosphorus uptake in the soils 2 and 3 by 35 and $42 \%$, respectively. Thus, it is possible that the ineffectiveness of the $\mathrm{Na}_{2}$-EDTA treatment in the soil sample $\mathrm{l}$ was seeming and partly connected to the restricted growth of the rye grass.

The irrigation with $\mathrm{Na}_{2}$-EDTA increased the uptake of aluminium by 33-120 $\%$ and that of iron by $217-458 \%$. Even if two harvests only were analysed for manganese, magnesium and calcium, the results give some intimations of the

Table 2. Yields of air dry matter ( $\mathrm{g} /$ pot $)$.

\begin{tabular}{llllccc}
\hline $\begin{array}{l}\text { Soil } \\
\text { sample }\end{array}$ & $\begin{array}{l}\text { Treat- } \\
\text { ment }\end{array}$ & 1st yield & 2nd yield & 3rd yield & 4th yield & $\Sigma$ \\
\hline $\begin{array}{l}1 \text { sandy } \\
\text { clay }\end{array}$ & $\mathrm{H}_{2} \mathrm{O}$ & $5.3 \pm 0.6$ & $4.7 \pm 0.4$ & - & $2.7 \pm 0.7$ & $12.6 \pm 1.5$ \\
$\mathrm{Na}_{2}$-EDTA & $5.5 \pm 0.5$ & $4.7 \pm 0.3$ & - & $1.3 \pm 0.5$ & $11.4 \pm 1.0$ \\
silt & $\mathrm{H}_{2} \mathrm{O}$ & $5.9 \pm 0.3$ & $5.3 \pm 0.2$ & $6.9 \pm 0.2$ & $1.3 \pm 0.1$ & $19.4 \pm 0.5$ \\
& $\mathrm{Na}_{2}$-EDTA & $5.8 \pm 0.4$ & $5.0 \pm 0.5$ & $6.6 \pm 0.4$ & $1.2 \pm 0.5$ & $18.5 \pm 1.5$ \\
3 silty & $\mathrm{H}_{2} \mathrm{O}$ & $5.3 \pm 0.1$ & $4.3 \pm 0.2$ & $6.6 \pm 0.3$ & $1.7 \pm 0.2$ & $17.9 \pm 0.5$ \\
clay & $\mathrm{Na}_{2}$-EDTA & $4.9 \pm 0.2$ & $4.2 \pm 0.2$ & $6.6 \pm 0.1$ & $1.6 \pm 0.6$ & $17.2 \pm 0.7$ \\
\hline
\end{tabular}


Table 3. Amounts of elements taken up by yields ( $\mathrm{mg} / \mathrm{kg}$ of soil).

\begin{tabular}{llrrrrrr}
\hline $\begin{array}{l}\text { Soil } \\
\text { sample }\end{array}$ & $\begin{array}{l}\text { Treat- } \\
\text { ment }\end{array}$ & $\mathrm{P}$ & $\mathrm{Al}$ & $\mathrm{Fe}$ & $\mathrm{Mn}^{*}$ & $\mathrm{Mg}^{*}$ & $\mathrm{Ca}^{*}$ \\
\hline $\begin{array}{l}\text { I sandy } \\
\text { clay }\end{array}$ & $\mathrm{H}_{2} \mathrm{O}$ & 36.8 & 1.0 & 1.5 & 1.4 & 33.3 & 53.3 \\
& & \pm 3.1 & \pm 0.4 & \pm 1.7 & \pm 0.2 & \pm 1.8 & \pm 4.7 \\
& $\mathrm{Na}_{2}$-EDTA & 35.7 & 1.7 & 5.6 & 1.7 & 37.9 & 62.4 \\
& & \pm 2.9 & \pm 0.8 & \pm 4.4 & \pm 0.3 & \pm 2.7 & \pm 4.3 \\
2 silt & & & & & & & \\
& $\mathrm{H}_{2} \mathrm{O}$ & 43.5 & 1.3 & 1.9 & 7.4 & 23.7 & 67.1 \\
& & \pm 3.1 & \pm 0.1 & \pm 0.1 & \pm 0.6 & \pm 0.8 & \pm 2.1 \\
& $\mathrm{Na}_{2}$-EDTA & 61.9 & 2.7 & 6.1 & 5.1 & 25.1 & 58.6 \\
& & \pm 2.7 & \pm 0.6 & \pm 0.8 & \pm 0.2 & \pm 3.0 & \pm 6.4 \\
3 silty & & & & & & & \\
clay & $\mathrm{H}_{2} \mathrm{O}$ & 37.6 & 2.0 & 2.1 & 4.1 & 15.4 & 77.6 \\
& & \pm 2.0 & \pm 0.3 & \pm 0.2 & \pm 0.1 & \pm 0.9 & \pm 4.1 \\
& $\mathrm{Na}_{2}$-EDTA & 51.0 & 2.7 & 7.5 & 3.4 & 19.6 & 71.4 \\
& & \pm 1.2 & \pm 0.3 & \pm 0.6 & \pm 0.3 & \pm 0.4 & \pm 2.9 \\
\hline
\end{tabular}

* taken up by two harvests

significance of chelation on the supply of these nutrients to the rye grass. In the silt and silty clay soil the chelating agent seemed not to affect the manganese content in the first yields but to decrease that in the second ones. In the sandy clay soil relatively rich in oxalate extractable reserves it tended contrarily to intensify the manganese absorption in the second yield. The differences between the treatments were not, however, statistically significant.

In the sandy clay soil the $\mathrm{Na}_{2}$-EDTA treatment tended to promote the calcium uptake by the plants, but the result remained statistically uncertain. In the other experimental soils the calcium content of the first yield was not affected and that of the second one was even reduced. On the other hand, the chelating agent had increased the magnesium absorption in the first yields of all the soil samples. In the second harvest this promoting effect was found only in the silty clay soil which is exceptionally poor in exchangeable magnesium.

At the end of the test the soil samples were analysed for some characteristics in order to elucidate reactions induced by the chelating compound during the period of growth. A layer resembling the enrichment horizon of a podsol soil was found in the lower part of the soil profile in the pots irrigated with $\mathrm{Na}_{2}$-EDTA. This supports the observation made by CHENG et al. (1972) that EDTA is easily leached in soil. The quartz sand added to the pots was found to have become mixed with the topmost soil layers, wherefore $4 \mathrm{~cm}$ of the uppermost soil layers were removed before the soil material was ground for the analyses.

The soil $\mathrm{pH}\left(\mathrm{CaCl}_{2}\right)$ in the pots irrigated with water had risen by $0.0-0.6$ units and in those treated with $\mathrm{Na}_{2}$-EDTA by $0.5-0.6$ units. Because the changes were of the same magnitude in both treatments they can hardly explain the differences in the accumulation of soil elements in the shoots.

The reactions of soil inorganic phosphorus were investigated by the fractionation analysis. The results tested by the DUNCAN method (STEEL and TORRIE 1960) at 95 per cent confidence level are given in Table 4. They show that quite a marked decrease in $\mathrm{NH}_{4} \mathrm{CI}-\mathrm{P}$ and $\mathrm{NH}_{4} \mathrm{~F}-\mathrm{P}$ had occurred during the period of growth. Also the $\mathrm{NaOH}$ soluble fraction tended to be reduced, although 
Table 4. P fractions $(\mathrm{mg} / \mathrm{kg})$ in original soils and soils after growing.*

\begin{tabular}{|c|c|c|c|c|c|}
\hline \multirow{2}{*}{$\begin{array}{l}\text { Soil } \\
\text { sample }\end{array}$} & \multirow{2}{*}{$\begin{array}{l}\text { Treat- } \\
\text { ment }\end{array}$} & \multicolumn{4}{|c|}{ P extracted sequentially by } \\
\hline & & $\mathrm{NH}_{4} \mathrm{Cl}$ & $\mathrm{NH}_{4} \mathrm{~F}$ & $\mathrm{NaOH}$ & $\mathrm{H}_{2} \mathrm{SO}_{4}$ \\
\hline \multirow{3}{*}{$\begin{array}{l}\text { l sandy } \\
\text { clay }\end{array}$} & Original & $2.3^{\mathrm{b}}$ & $47^{c}$ & $332^{a}$ & $154^{a}$ \\
\hline & $\mathrm{H}_{2} \mathrm{O}$ & $1.2^{\mathrm{a}}$ & $29^{a}$ & $282^{\mathrm{a}}$ & $141^{\mathrm{a}}$ \\
\hline & $\mathrm{Na}_{2}$-EDTA & $1.1^{\mathrm{a}}$ & $33^{b}$ & $285^{a}$ & $142^{\mathrm{a}}$ \\
\hline \multirow[t]{3}{*}{2 silt } & Original & $9.3^{b}$ & $91^{\mathrm{c}}$ & $123^{\mathrm{C}}$ & $403^{a}$ \\
\hline & $\mathrm{H}_{2} \mathrm{O}$ & $5.5^{\mathrm{a}}$ & $52^{\mathrm{a}}$ & $109^{b}$ & $403^{a}$ \\
\hline & $\mathrm{Na}_{2}$-EDTA & $5.2^{\mathrm{a}}$ & $72^{\mathrm{b}}$ & $101^{\mathrm{a}}$ & $402^{\mathrm{a}}$ \\
\hline \multirow{3}{*}{$\begin{array}{r}3 \text { silty } \\
\text { clay }\end{array}$} & Original & $3.4^{\mathrm{c}}$ & $120^{c}$ & $512^{\mathrm{a}}$ & $181^{\mathrm{a}}$ \\
\hline & $\mathrm{H}_{2} \mathrm{O}$ & $2.8^{\mathrm{b}}$ & $99^{\mathrm{a}}$ & $485^{\mathrm{a}}$ & $181^{\mathrm{a}}$ \\
\hline & $\mathrm{Na}_{2}$-EDTA & $2.1^{\mathrm{a}}$ & $105^{b}$ & $481^{a}$ & $176^{a}$ \\
\hline
\end{tabular}

- Each sample and fraction has been tested separately. Means followed by a common letter do not differ at $\mathrm{P}=$ 0.05 .

the decrease was not always statistically significant owing to the great variation between the replicates. Further, the $\mathrm{NH}_{4} \mathrm{~F}$ extractable fraction was more depleted in the pots irrigated with water than in those irrigated with $\mathrm{Na}_{2}$-EDTA, while on the other hand, the residual $\mathrm{NaOH}-\mathrm{P}$ tended to be greater in the water treatment.

\section{Discussion}

The results obtained in the present study show that the $\mathrm{Na}_{2}$-EDTA treatment affected more the quality than the quantity of the yields. In two soils it markedly improved the phosphorus absorption by the plants. However, owing to the great variation between the replicates, it was not possible by means of the fractionation analysis quantitatively to explain the differences in the phosphorus supply between the water and $\mathrm{Na}_{2}$-EDTA treatments. Yet, it can be concluded that in the pots irrigated with water $\mathrm{NH}_{4} \mathrm{~F}-\mathrm{P}$ was relatively more effectively depleted than $\mathrm{NaOH}$ P. On the contrary, the chelating compound seemed somewhat to intensify the mobilization of phosphorus in the $\mathrm{NaOH}$ soluble fraction supposed to be bound by iron. Nevertheless, the greater residual $\mathrm{NH}_{4} \mathrm{~F}-\mathrm{P}$ in the pots treated with $\mathrm{Na}_{2}$-EDTA does not necessarily evidence that the chelating agent would have reduced the availability of these reserves assumed to be bound by aluminium. An earlier study of HARTIKAINEN (1979) on Finnish mineral soils showed that some resorption of mobilized phosphorus into the $\mathrm{NH}_{4} \mathrm{~F}$ soluble form can occur during the $\mathrm{Na}_{2}$-EDTA extraction. Moreover, the residual $\mathrm{NH}_{4} \mathrm{~F}-\mathrm{P}$ may include some phosphorus leached from the uppermost soil layers removed before the soil analyses.

The intensified phosphorus supply due to the addition of the complexant may partly be due to an increase in $\mathrm{NH}_{4} \mathrm{~F}-\mathrm{P}$, in most soils found to be more available to plants than NaOH-P (e.g. MacKENZIE 1962). Further, the ratio of secondary phosphates to sorptive compounds is supposed to be of primary significance in the phosphorus desorption in a given fraction (HARTIKAINEN 1979). The soil sample 1 (sandy clay) was quite poor in secondary phosphates as compared with the oxalate extractable iron, aluminium and manganese reserves. This may partly explain 
the rather low efficiency of $\mathrm{Na}_{2}$-EDTA to intensify the phosphorus supply to plants in this soil.

The intensified uptake of phosphorus seemed not to affect the dry matter yields. This was obviously due to the simultaneously increased accumulation of iron and aluminium in the plants, which caused disturbance in the plant growth. It was clearly noticed that the greater the stability constant for the metal-EDTA complex was (according to LINDSAY 1979) the more strongly the content of this metal in the plant material tended to increase. Of the metals studied, the most stabile EDTA complex is formed with iron, aluminium being the next and manganese the weakest. So, the enormously increased accumulation of iron in the shoots induced by the $\mathrm{Na}_{2}$ EDTA treatment is in accordance with the conclusions drawn from the results of phosphorus fractionation.

The irrigation with $\mathrm{Na}_{2}$-EDTA likely led to some inbalance in the metal concentrations in the plants. On the basis of the first two harvests particularly the ratio of iron to manganese seemed to increase. The decreased content of manganese in the second yield is in conformity with the experimental results published by many earlier investigators. For example, KNEZEK and GREINERT (1971) and NABHAN et al. (1977) have detected a similar reduction in manganese uptake due to the addition of chelating agent or iron chelates to the soil. This phenomenon might be explained by the antagonistic effect of iron and its higher solubility in the soil treated with chelating compound. Manganese chelates are known even to intensify manganese deficiency, because manganese is released from the ligand which is able to make iron more available, causing an inbalance in the ratio of iron to manganese in plants (KNEZEK and GREINERT 1971).

The plants irrigated with water absorbed relatively small amounts of aluminium. The total uptake corresponded to $0.8-10.2 \%$ of exchangeable reserves. Chelation reactions likely increased the total concentration of aluminium in the soil solution, enhancing the accumulation of this element in the tops of the rye grass. The ability of chelating agent to maintain or increase concentrations of soluble elements in the soil solution can be explained by the fact that the chelating ligand is quite ineffectively absorbed by plants. Especially at low concentrations the metal is separated from the chelating compound at the root surface and only the metal is absorbed (TIFFIN and BROWN 1959, 1961). At high concentrations some metal chelates may, however, be absorbed by plants (HILL-GOTTINGHAM and LLOYD-JONES 1965, JEFFREYS and WALLACE 1968).

An exceptionally high aluminium concentration and a markedly lowered ratio of phosphorus to aluminium in the last yield of the sandy clay soil (1) indicate that the reduced plant growth and the inefficiency of the $\mathrm{Na}_{2}$-EDTA solution to improve phosphorus uptake might be partly caused by an excess of aluminium. In the other soil samples of better phosphorus status the chelating agent was able to enhance the total phosphorus accumulation in the tops.

The mechanism of the aluminium toxity is suggested to be the inactivation of phosphorus especially in the roots. According to CLARKSON (1966), aluminium inhibits the esterification of phosphate, a prerequisite for phosphate transport to tops. Further, it should be taken into account that the abnormal root development owing to the accumulation of aluminium in roots (CLARKSON 1966) may even physically restrict the phosphorus supply, because an adequate exploitation of soil 
phosphorus reserves considerably depends on a well-developed root system (BALDWIN 1975).

The chemical analysis of the root matter would have elucidated the reactions of soil aluminium induced by chelation. However, the increase in the aluminium uptake by the tops suggests that some of this element was available for the translocation. FOY et al. $(1967,1972)$ have presented that the amount translocated reflects the aluminium tolerance of some plant species.

The resources of exchangeable magnesium and calcium in the soil samples seemed to meet the requirements of the rye grass. It can be calculated that in the water treatment the first two harvests removed 4,12 and $21 \%$ of the exchangeable magnesium and 2, 3 and 5\% of the exchangeable calcium from the sandy clay, silt and silty clay soil, respectively.

On the basis of the first two harvests it seems obvious that owing to their weak affinity to form stable EDTA compounds, magnesium and calcium were not able significantly to compete with other elements studied for the complexing ligand. Even if the stability constant for the Ca-EDTA chelate is greater than that for the corresponding magnesium compound, the chelate treatment somewhat tended to improve the uptake of magnesium and to diminish that of calcium. It is possible that especially in the silty clay soil (3) very poor in exchangeable magnesium the chelation reactions increased the concentration of total soluble magnesium in the soil solution and improved the supply to plants. The quantities of calcium in the soils were so great that a possible increase in soluble form was of no significance in regard to the requirements of plants. Futhermore, the presence of the chelating agent may interfere with calcium nutrition, because chelated calcium has been found to be less available than $\mathrm{Ca}^{2+}$ ion (ELGAWHARY and BARBER 1973, MALZER and BARBER 1976).

The magnesium and calcium content in the rye grass was not found to be connected with the aluminium uptake. However, according to HUETT and MENARY (1979), aluminium uptake is passive and the initial process involves exchanging calcium from free space. Some recent studies made by nutrient solutions show the uptake of these elements to decrease with increasing aluminium level (ALAM and ADAMS 1980, HUETT and MENARY 1980).

The results of the present study are in accordance with the conception that under certain circumstances the complexation reactions may be of significance in improving the availability of soil phosphorus. The use of synthetic compounds for this purpose is, however, problematic, because the intensified phosphorus supply seems to be associated with the simultaneously increasing accumulation of metals, difficult to control. Further, the experiment supports the experience that the effect of fertilizer chelate used for the correction of some micronutrient deficiency can be uncertain. Other cations in the soil may displace the added metal and render it ineffective or even cause some inbalance in the nutrient ratios in plants. This problem may arise primarily in horticultural soils, chelate fertilizers being rather rarely used in agricultural soils. The influence of chelators, natural or synthetic, should be taken into account when metal polluted soils are cultivated.

On the basis of the experimental results, the suitability of $\mathrm{Na}_{2}$-EDTA solution for the determination of phosphorus reserves available to plants seems doubtful in Finnish soils. Obviously, the amounts extracted describe the resources possible to render available rather than reserves available per se. 


\section{References}

ALAM, S. M. \& ADAMS, W. A. 1980. Effect of aluminium on plant growth and mineral nutrition of barley. Pak. J. Bot. 12: 107-113.

BALDWIN, J. P. 1975. A quantitative analysis of the factors affecting plant nutrients uptake from some soils. J. Soil Sci. 26: 195-206.

CHANG, S. C. \& JACKSON, M. L. 1957. Fractionation of phosphorus. Soil Sci. 84: 133-144.

CHENG, S. M., THOMAS, R. L. \& ELRICK, D. E. 1972. Reactions and movement of EDTA and Zn EDTA in soils. Can. J. Soil Sci. 52: 337-341.

CLARKSON, D. T. 1966. Effect of aluminum on the uptake and metabolism of phosphorus by barley seedlings. Pl. Physiol. 41: 165-172.

ELGAWHARY, S. M. \& BARBER, S. A. 1973. Measurement of uptake of chelated and unchelated Ca and Sr from solution culture. Plant and Soil 39: 581-590.

ELONEN, P. 1971. Particle-size analysis of soil. Acta Agr. Fenn. 122: 1-122.

FOY, C. D., FLEMING, A. L., Burns, G. R. \& ARMIGER, W. H. 1967. Characteruzation of differential aluminium tolerance among varieties of wheat and barley. Soil Sci. Soc. Amer. Proc. 31: 513-521.

- , FLEMING, A. L. \& GERLOFF, G. C. 1972. Differential aluminum tolerance in two snapbean varieties. Agron. J. 64: 815-818.

GRAHAM, E. R. 1948. Determination of soil organic matter by means of a photoelectric colorimeter. Soil Sci. 65: $181-183$.

HARTIKAINEN, H. 1979. Phosphorus and its reactions in terrestrial soils and lake sediments. J. Scient. Agric. Soc. Finl. 51: 537-624.

HILL-COTTINGHAM, D. G. \& LLOYD-JONES, C. P. 1965. The behavior of iron chelating agents with plants. J. Exp. Bot. 16: 233-242.

HUETT, D. O. \& MENARY, R. C. 1979. Aluminium uptake by excised roots of cabbage, lettuce and kikuyu grass. Aust. J. Pl. Physiol. 6: 643-653.

- \& MENARY, R. C. 1980. Effect of aluminium on growth and nutrient uptake of cabbage, lettuce and kikuyu grass in nutrient solution. Aust. J. Agric. Res. 31: 749-761.

JEFFREYS, R. A. \& Wallace, A. 1968. Detection of iron ethylenediamine di(o-hydroxyphenylacetate) in plant tissue. Agron. J. 60:613-616.

KOUTLER-ANDERSSON, E. 1953. The sulfosalisylic acid method for iron determination and its use in certain soil analyses. Ang. R. Agric. Coll. Swed. 20: 297-301.

KNEZEK, B. D. \& GREINERT, H. 1971. Influence of soil Fe and MnEDTA interactions upon the Fe and Mn nutrition of bean plants. Agron. J. 63: 617-619.

LINDSAY, W. L. 1979. Chemical equilibria in soils. 449 p. New York.

MacKENZIE, A. F. 1962. Inorganic soil phosphorus fractions of some Ontario soils as studied using isotope exchange and solubility criteria. Can. J. Soil Sci. 42: 150-156.

MALZER, G. L. \& BARBER, S. A. 1976. Calcium and strontium absorption by corn roots in the presence of chelates. Soil Sci. Soc. Amer. J. 40: 727-731.

NABHAN, H. M., VANDERDEELEN, J. \& COTTENIE, A. 1977. Chelate behaviour in saline-alkaline soil conditions. Plant and Soil 46: 603-618.

STEEL, R. G. D. \& TORRIE, J. H. 1960. Principles and procedures of statistics. 481 p. New York.

TIFFIN, L. O. \& BROWN, J. C. 1959. Absorption of iron from iron chelate by sunflower roots. Science 130: 274-275.

- \& BROWN, J. C. 1961. Selective absorption of iron from iron chelates by soybean plants. Pl. Physiol. 36: 710-714.

YUAN, T. L. \& FISKELL, J. G. A. 1959. Aluminum determination. Aluminum studies. Soil and plant analysis of aluminum by modification of the Aluminon method. J. Agr. Food Chem. 7: 115-117.

Ms received May 25, 1981. 


\section{Synteettisen kelaatinmuodostajan vaikutus Italian raiheinän (Lolium multiflorum Lam). P:n, Al:n, Fe:n, Mn:n, Mg:n ja Ca:n saantiin maasta}

\section{Helinä Hartikainen}

Helsingin yliopiston maanviljelyskemian laitos, 00710 Helsinki 71

Kolmella muokkauskerrosta edustaneella kivennäismaanãytteellä tehdyssä astiakokeessa vertailtiin vedellä tai $0.001 \mathrm{M} \mathrm{Na}_{2}$-EDTA:Ila kasteltujen koejäsenten kuiva-ainesatoja ja niiden kemiallista koostumusta. Kaikista sadoista määritettiin $\mathrm{P}: \mathrm{n}, \mathrm{Al}: \mathrm{n}$ ja $\mathrm{Fe}: \mathrm{n}$ pitoisuudet, kahdesta ensimmäisestä myös $\mathrm{Mn}: \mathrm{n}, \mathrm{Mg}: \mathrm{n}$ ja $\mathrm{Ca}: \mathrm{n}$ pitoisuudet.

$\mathrm{Na}_{2}$-EDTA-käsittely ei vaikuttanut merkittävästi satojen määrään, mutta sen sijaan niiden alkuainepitoisuuksiin ja joidenkin alkuaineiden keskinäisiin suhteisiin. Kaikissa maanäytteissä se nosti satojen $\mathrm{P}: \mathrm{n}, \mathrm{Al}: \mathrm{n}$ ja $\mathrm{Fe}: \mathrm{n}$ pitoisuutta. Fraktiointianalyysin perusteella nãytti $\mathrm{Na}_{2}$-EDTA mobilisoineen maan fosforia lähinnä raudan sitomiksi oletetuista $\mathrm{NaOH}$-liukoisista varoista. Kahden maanãytteen kohdalla havaittu varsin huomattava maan P-reservien hyväksikäytōn paraneminen $(35-42 \%)$ ei kuitenkaan vaikuttanut kuivaainesatojen suuruuteen, minkä arveltiin johtuneen samanaikaisesti lisääntyneestä metallien kertymisestä kasveihin.

Aluminiumin, raudan ja mangaanin kertymisen voimistuminen $\mathrm{Na}_{2}$-EDTA-käsittelyn seurauksena näytti kytkeytyvãn metallin ja EDTA:n muodostaman kompleksin stabiilisuusvakion arvoon. Tutkituista metalleista rauta muodostaa pysyvimmän kompleksin ja sen otto lisääntyi $217-458 \%$, seuraavana aluminium, jonka määrä sadoissa kasvoi 33-120\%. Kahden ensimmäisen sadon perusteella nãytti kasvien Mn:n otto vähentyneen todennäköisesti raudan liiallisen kertymisen seurauksena.

Magnesiumin ja kalsiumin kohdalla tulokset viittasivat siihen, ettei $\mathrm{Na}_{2}$-EDTA:n lisääminen maahan pystynyt olennaisesti lisäämään niiden ottoa.

Koetulokset tukevat käsitystä, ettã orgaaniset komplekseja muodostavat yhdisteet voivat parantaa maan fosforin hyväksikäyttöä. Synteettisten yhdisteiden käyttämistä tähän tarkoitukseen ei voida kuitenkaan suoralta kädeltä suositella, koska ne voivat samanaikaisesti lisätä metallien kertymistä kasveihin. Kompleksinmuodostusreaktiot on otettava huomioon myös valittaessa viljelyskasvia ja viljelymenetelmiä alueilla, joilla maaperään on kertynyt tai siinä on luotaisesti runsaasti metalleja. 